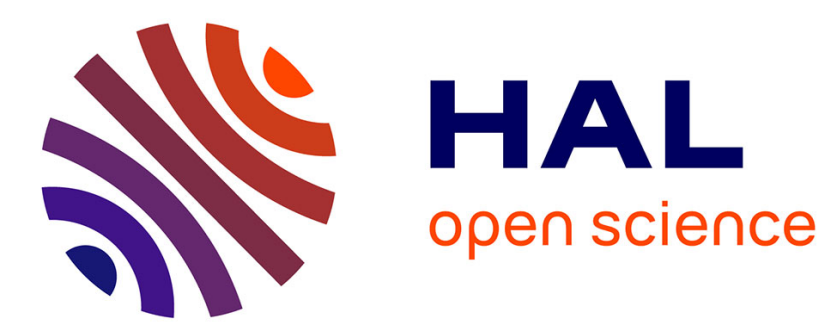

\title{
Numerical simulation of flow field in water-pump sump and inlet suction pipe
}

Annie-Claude Bayeul-Laine, Gérard Bois, Abir Issa

\section{To cite this version:}

Annie-Claude Bayeul-Laine, Gérard Bois, Abir Issa. Numerical simulation of flow field in water-pump sump and inlet suction pipe. IOP Conference Series: Earth and Environmental Science, 2010, pp.1-9. 10.1088/1755-1315/12/1/012083 . hal-00785816

\section{HAL Id: hal-00785816 https://hal.science/hal-00785816}

Submitted on 7 Feb 2013

HAL is a multi-disciplinary open access archive for the deposit and dissemination of scientific research documents, whether they are published or not. The documents may come from teaching and research institutions in France or abroad, or from public or private research centers.
L'archive ouverte pluridisciplinaire HAL, est destinée au dépôt et à la diffusion de documents scientifiques de niveau recherche, publiés ou non, émanant des établissements d'enseignement et de recherche français ou étrangers, des laboratoires publics ou privés. 


\title{
Numerical Simulation of Flow Field in Water-Pump Sump and Inlet Suction Pipe
}

\author{
Annie-Claude Bayeul-Lainé ${ }^{1}$, Gérard Bois ${ }^{1}$ and Abir Issa ${ }^{2}$ \\ ${ }^{1}$ LML, UMR CNRS 8107, Arts et Metiers PARISTECH, \\ 8, boulevard Louis XIV 59046 LILLE Cedex, France, annie-claude.bayeul@ensam.eu, \\ gerard.bois@ensam.eu \\ ${ }^{2}$ Faculté de Génie Civil, Université de Damas \\ Baramkeh-Mazzé, Syrie, Abir.issa1010@gmail.com
}

\begin{abstract}
There are several important considerations in the design of a suction supply sump. It is imperative that the amount of turbulence and entrained air be kept to a minimum. Free air-core vortex occurring at a water-intake pipe is an important problem encountered in hydraulic engineering. These vortices may reduce pump performances, have large effects on the operating conditions and lead to increase plant operating costs. Experiments, conducted in order to select best positions of the suction pipe of a water-intake sump, show qualitative results concerning flow disturbances in the pump-intake related to sump geometries and position of the pump intake. The purpose of the paper is to reproduce the flow pattern and confirm the geometrical parameter influences of the flow behavior in such a pump. The numerical model used solves the Reynolds averaged Navier-Stokes (RANS) equations and VOF multiphase model for two cases. In the validation of this numerical model, emphasis was placed on the prediction of the number, location, size and strength of the various types of vortices. Previous studies, without simulation of air entrainment, have shown the influence on a single type of mesh with different cell numbers, different intake pipe depths and different water levels, for two turbulence models closure.
\end{abstract}

Keywords: Pump sump-Open channel flow- Free surface vortices-submerged vortices-air entraining- CFD-Turbulent modelNumerical simulation.

\section{Introduction}

This work is an extended study starting from 2006 (ISSA [10]) in LML and first published by ISSA and al. in 2008 and 2009 ([8] and [9]). Several cases of sump configuration have been numerically investigated using one specific commercial code and based on the initial geometry proposed by Constantinescu and Patel([3,4]). The results, obtained with a structured mesh, were strongly dependant on main geometrical sump configuration such as the suction pipe position, the submergence of the suction pipe on one hand and the turbulence model on the other hand. Part of the results shows a good agreement with experimental investigations already published by the Iowa Institute of Hydraulic Research (Nakato [12] to [15]; Ettema and Nakato [6]) to reduce non uniformities of specific flow and geometrical conditions. More basic studies have been also conducted to establish empirical criteria for vortex formation and avoidance (Anvar ([1]), Anvar and Amphlett ([2]), Daggett and Keulegan ([5])).

The use of numerical approach starts with Tagomori and Gotoch ([16]) (1989) in order to study the effects of non uniform inlet flow on vortex generation and the effects of additional devices to prevent vertical flow formation. They have used a finite volume method to solve the RANS equations with the k- $\varepsilon$ model. Takata and al. ([17]) (1992) report large eddy simulations of pump intake flows at low Reynolds number $\left(10^{4}\right)$.

More recently, CFD Benchmarks have been performed by Matsui and al. ([11]) in order to compare different software results with experiments.

New numerical investigations using different mesh structures and another CFD code are presented in this paper in order to compare results and determine why results can be equivalent or different. 


\section{Sump and inlet pipe geometry test cases}

Four geometric cases are presented in this paper:

- $\quad$ Case a: based on the Constantinescu and Patel's one ([3]) in which thickness of pipe is neglected (Fig. 1). The intake pipe is located in the middle of sump width $\left(b_{1}=b_{2}=1.3 \mathrm{~d}\right)$ at a fixed value of $1(1=0.9 \mathrm{~d})$ from the back wall. The submergence is equal to $2 \mathrm{~d}$ and clearance distance $\mathrm{z}$ from floor is equal to $0.75 \mathrm{~d}$ (with $\mathrm{d}=0.1 \mathrm{~m}$ ).

- $\quad$ Case $b$ : based on the same model in which thickness is taken account $(0.5 \mathrm{~mm})$

- $\quad$ Case c : same model as cases a and b but with bellmouth ( $\left.D=1.5 \mathrm{~d}, \mathrm{~h}_{\mathrm{b}}=1.083 \mathrm{~d}\right)$ (Fig. 2$)$

- $\quad$ Case d: same model as case $c$ with two fluids where $h_{\text {air }}$ equal $1 d$ (Fig. 3 ).

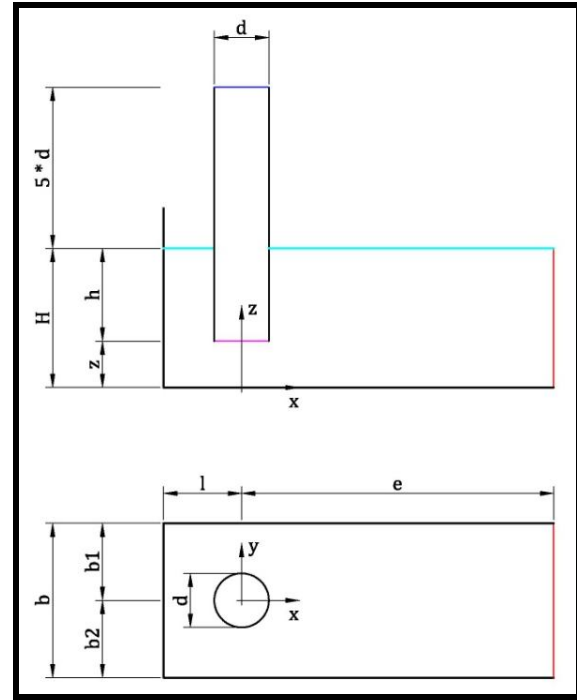

Fig. 1 Geometrical parameters

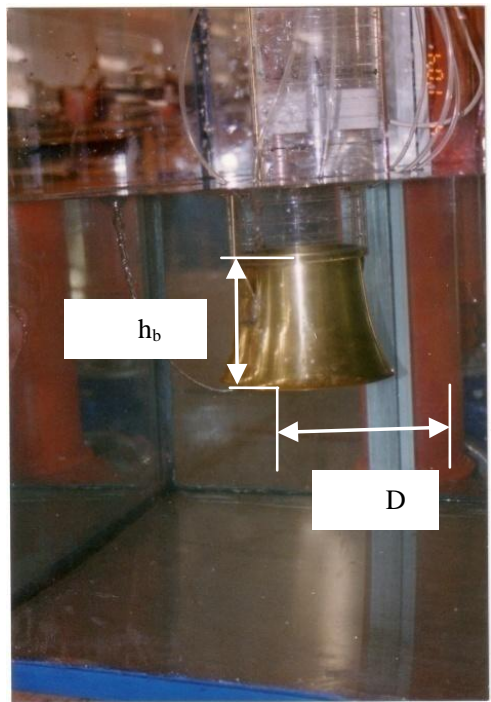

Fig. 2 Parameters for bellmouth

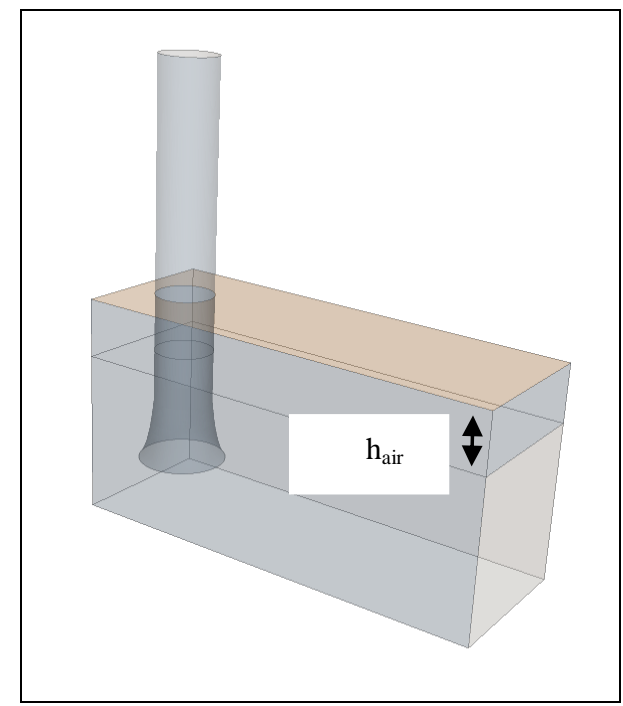

Fig. 3 Model with two phases

\section{Grids and simulations}

\subsection{Tests cases}

The calculation domain of case a is divided into three different blocks as shown in ISSA ([8]). The resulting computational grid is a structured hexahedral grid with about 592000 cells shown in Fig. 4. We can see details of mesh inside pipe on the right of Fig. 4.

In case $b$, polyhedral mesh with prism layer thickness is used (target size $0.1 \mathrm{~d}$, total prism layer tkickness equal to $0.01 \mathrm{~d}$ for 5 prism layers and prism layer stretching 1.5. Details of mesh inside pipe can be seen on the right of Fig. 5. A rectangular refined mesh around tube is also used in which target size is divided by 2 . The resulting computational grid is a polyhedral grid with about 491000 cells.

In case $\mathrm{c}$ (with bellmouth), all other meshing parameters are the same as those used in case b (polyhedral mesh with 549200 cells)

In case $\mathrm{d}$, which is an attempt to calculate two phase flux, a new volume is added to simulate air over water and to try to avoid using symmetry condition at free surface.

All simulations were realized with one or two of these CFD codes : FLUENT and STAR CCM+.

All the cases are summarized on table 1 .

\section{Table 1 Tests list}

\begin{tabular}{|c|c|c|c|c|c|c|c|c|}
\hline $\begin{array}{l}\text { Computational } \\
\text { code }\end{array}$ & $\begin{array}{c}\text { Turbulence } \\
\text { model }\end{array}$ & Cases & $\begin{array}{l}\text { Boundary } \\
\text { conditions }\end{array}$ & $\mathbf{R e}$ & Fr & We & $\begin{array}{c}\text { Number } \\
\text { of cells }\end{array}$ & mesh \\
\hline \multirow[t]{2}{*}{ FLUENT } & $\mathrm{k}-\varepsilon$ & $a_{1}$ & $\mathrm{BC} 1$ & \multirow[t]{6}{*}{29285} & \multirow[t]{6}{*}{0.023} & \multirow[t]{6}{*}{119} & \multirow[t]{5}{*}{592000} & \multirow[t]{5}{*}{ structured } \\
\hline & $\mathrm{k}-\omega$ & $a_{2}$ & $\mathrm{BC} 1$ & & & & & \\
\hline \multirow[t]{10}{*}{ STAR CCM+ } & $\mathrm{k}-\varepsilon$ & $a_{3}$ & $\mathrm{BC} 1$ & & & & & \\
\hline & $\mathrm{k}-\omega$ & $a_{4}$ & BC1 & & & & & \\
\hline & $\mathrm{k}-\varepsilon$ & $a_{5}$ & $\mathrm{BC} 2$ & & & & & \\
\hline & & $\mathrm{b}_{1}$ & $\mathrm{BC} 2$ & & & & \multirow[t]{3}{*}{491000} & \multirow[t]{7}{*}{ unstructured } \\
\hline & & $\mathrm{b}_{2}$ & BC3 & 146423 & 0.115 & 2978 & & \\
\hline & & $\mathrm{b}_{3}$ & $\mathrm{BC} 4$ & 292845 & 0.223 & 11911 & & \\
\hline & & $\mathrm{c}_{1}$ & $\mathrm{BC} 2$ & 29285 & 0.023 & 119 & \multirow[t]{3}{*}{549200} & \\
\hline & & $\mathrm{c}_{2}$ & BC3 & 146423 & 0.115 & 2978 & & \\
\hline & & $c_{3}$ & $\mathrm{BC} 4$ & 292845 & 0.223 & 11911 & & \\
\hline & & $\mathrm{d}$ & BC6 & 146423 & 0.115 & 2978 & 750150 & \\
\hline
\end{tabular}




\subsection{Grids}

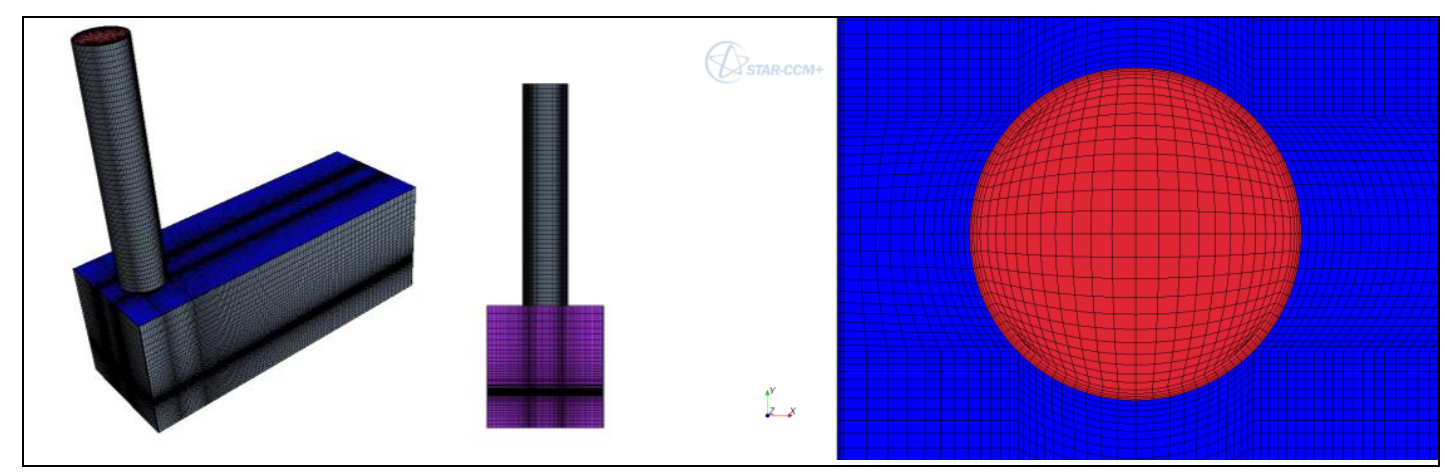

Fig. 4 Structured mesh, case a

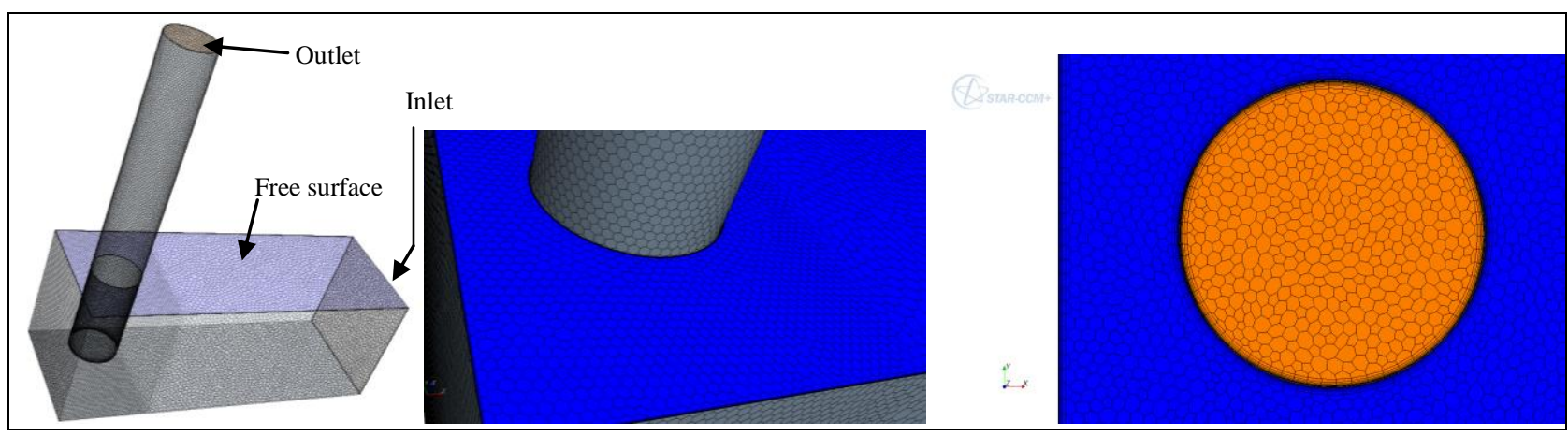

Fig. 5 Unstructured mesh, case b

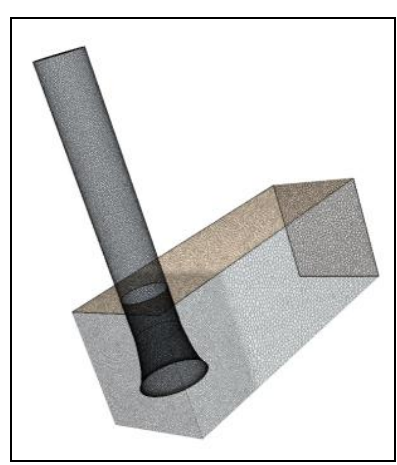

Fig. 6 Unstructured mesh, case c

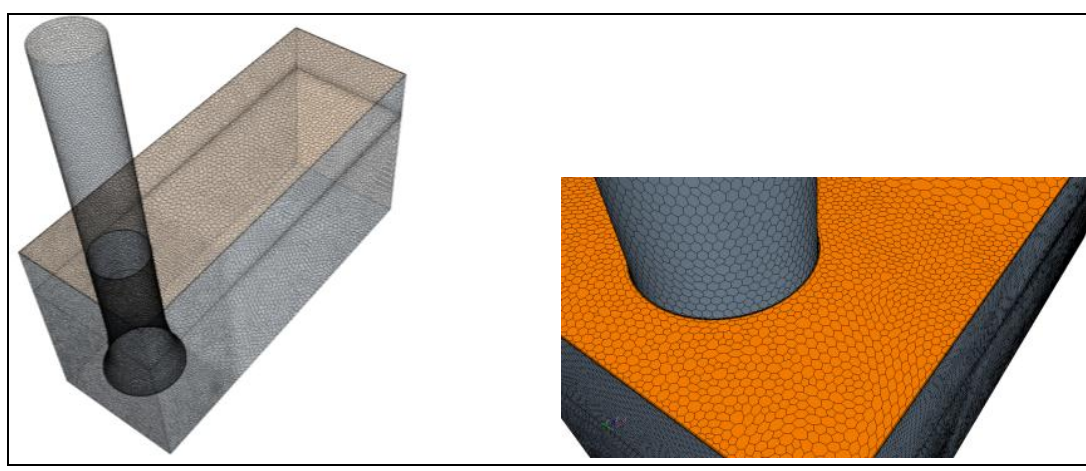

Fig. 7 Unstructured mesh, case d

\subsection{Boundary conditions}

Six types of conditions were tested:

- $\quad$ BC1 : Inlet=pressure (relative pressure $=0 \mathrm{~Pa})$, outlet=velocity $(\mathrm{v}=0.286 \mathrm{~m} / \mathrm{s})$, free surface $=$ symmetry

- $\quad$ BC2 : Inlet $=$ mass flow inlet $(\mathrm{qm}=2.3 \mathrm{~kg} / \mathrm{s})$, outlet=pressure (relative pressure $=0 \mathrm{~Pa})$, free surface $=$ symmetry

- $\quad$ BC3: Inlet=mass flow inlet $(\mathrm{qm}=11.5 \mathrm{~kg} / \mathrm{s})$, outlet=pressure (relative pressure $=0 \mathrm{~Pa})$, free surface $=$ symmetry

- $\quad$ BC4: Inlet=mass flow inlet $(\mathrm{qm}=23 \mathrm{~kg} / \mathrm{s})$, outlet=pressure (relative pressure $=0 \mathrm{~Pa})$, free surface $=$ symmetry

- $\quad$ BC5 : for the two phase model, inlet=mass flow inlet $(\mathrm{qm}=2.3 \mathrm{~kg} / \mathrm{s})$, outlet=mass flow inlet $(\mathrm{qm}=2.3 \mathrm{~kg} / \mathrm{s})$, upper surface (upper air)=pressure outlet with mass flow inlet $=0 \mathrm{~kg} / \mathrm{s}$

- $\quad$ BC6 : for the two phase model, inlet=mass flow inlet $(\mathrm{qm}=11.5 \mathrm{~kg} / \mathrm{s})$, outlet=mass flow inlet $(\mathrm{qm}=11.5 \mathrm{~kg} / \mathrm{s})$, upper surface (upper air)=pressure outlet with mass flow inlet $=0 \mathrm{~kg} / \mathrm{s}$

\section{Results}

An important feature is to decide how to present results in such configurations. We have decided to present:

- Contours of tangential velocities, helicity and vorticity magnitudes on the fluid surface and inside the tube at same level. For each case, only tangential velocity, using the same scale can show the overall flow feature inside the sump and the inside the tube.

- Some vorticity values on the symmetrical plane $x=0$ and on the plane $y=0$ (scale must be adapted for each case)

- $\quad$ Streamlines issued from free surface 
We are going to present part of the results for clarity and paper length.

\section{1 comparisons on test cases $a_{i}$ with two CFD codes}

Using k- $\varepsilon$ model, the two CFD codes (cases $\mathrm{a}_{1}, \mathrm{a}_{3}$ ) show some flow pattern of streamlines as shown on Figs. 8a and 8c. Using k- $\omega$ model (cases $\mathrm{a}_{2}$ and $\mathrm{a}_{4}$ ), the flow pattern is completely different as shown on Figs. $8 \mathrm{~b}$ and 8d. For this last case (8d), a strong asymmetry occurs which cannot be explained at that time. For this reason, all other test cases shown in this paper are obtained using k- $\varepsilon$ model with STAR CCM+.

Vorticity are shown respectively Figs. 9a and $9 \mathrm{~b}$ using the same scale. The two codes point out local recirculating zones just after the pipe inlet. Symmetrical results are also obtained in plane $\mathrm{x}=0$ (Fig. 9a) with a more important recirculation zone using FLUENT code. For plane $\mathrm{y}=0$ (Fig. 9b) asymmetric results are similar with more extension using FLUENT.

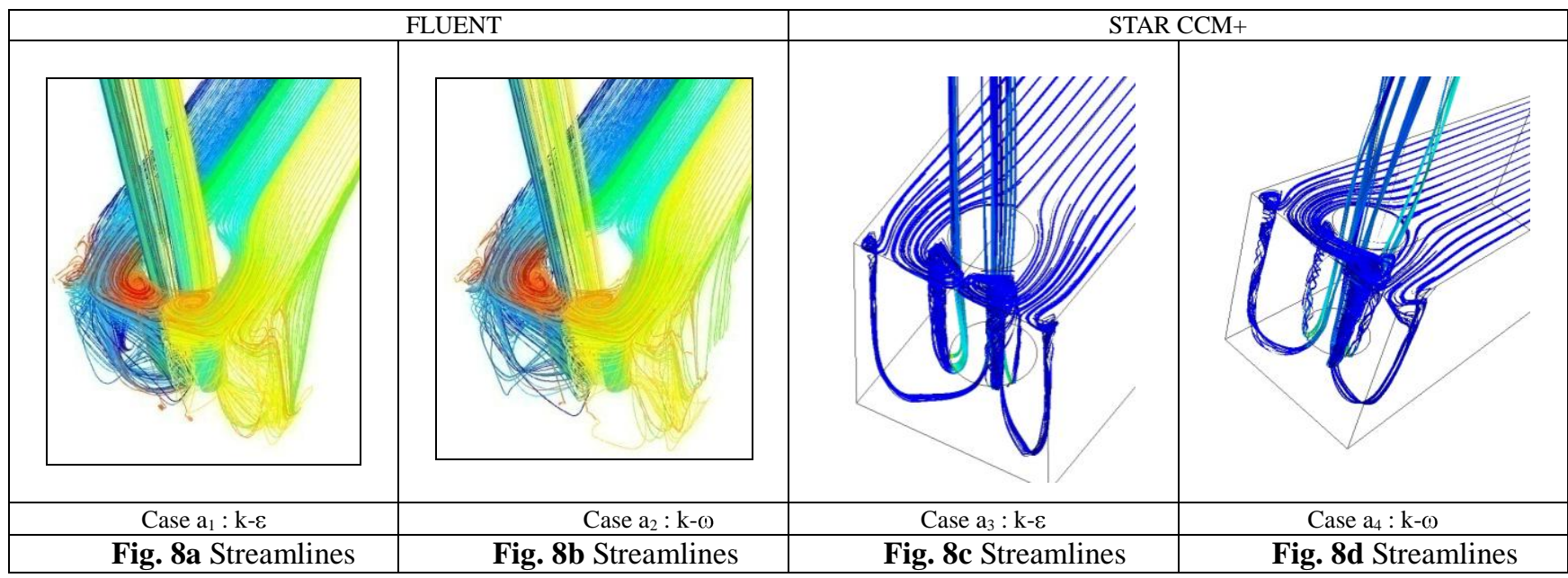

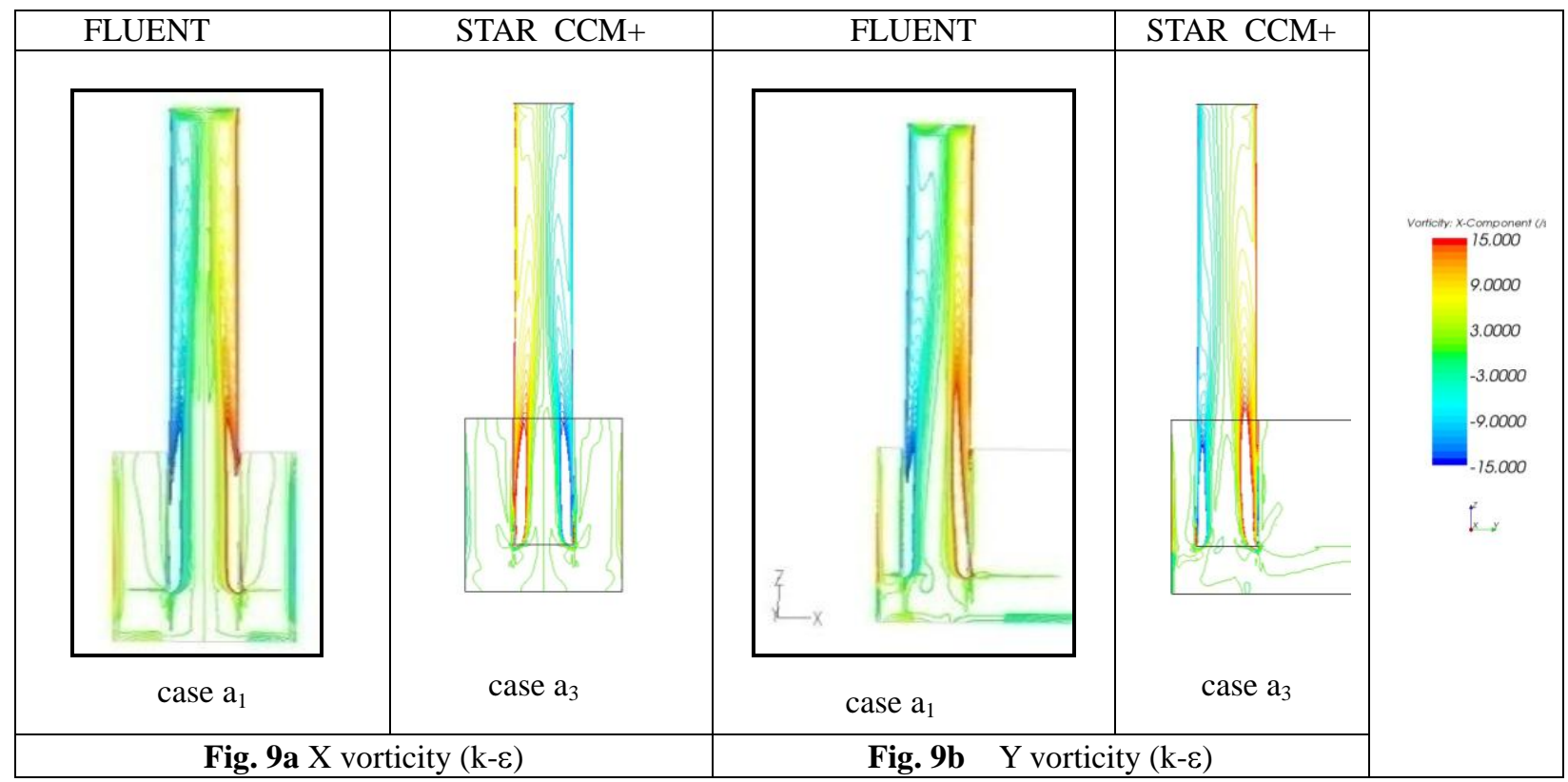

\subsection{Comparison of results with same CFD and different mesh configuration ( cases $a_{3}, a_{5}, b_{1}, b_{2}, b_{3}$ )}

These results are issued using $\mathrm{k}-\varepsilon$ model.

Results obtained with STAR CCM+ (Fig. 10, cases $\mathrm{a}_{3}$ and $\mathrm{a}_{5}$ ) with different boundary conditions (BC1 and BC2 : see table 1) for the same mass flow rate $(\mathrm{Re}=29285 ; \mathrm{Fr}=0,0384$; We=119) show good agreements.

Comparison between $a_{5}$ and $b_{1}$ corresponding to the same mass flow rate $(\operatorname{Re}=29285 ; \mathrm{Fr}=0,023$; We $=119)$ but for different mesh types and size also show some kind of results instead of inside of the tube.

Last comparison between $b_{1}, b_{2}, b_{3}$ (Fig. 10) is related to the influence of mass flow rate increasing from $b_{1}$ to $b_{3}$ up to some equivalent to $\mathrm{Re}=292845 ; \mathrm{Fr}=0,23 ; \mathrm{We}=11910$.

Non symmetric pattern appears when mass flow rate increase. It seems that asymmetric for plane $y=0$ starts from a particular mass flow rate $(\operatorname{Re}>50930, \mathrm{Fr}>0,04 ; \mathrm{We}>360)$

This effect had already been pointed up experimentally 


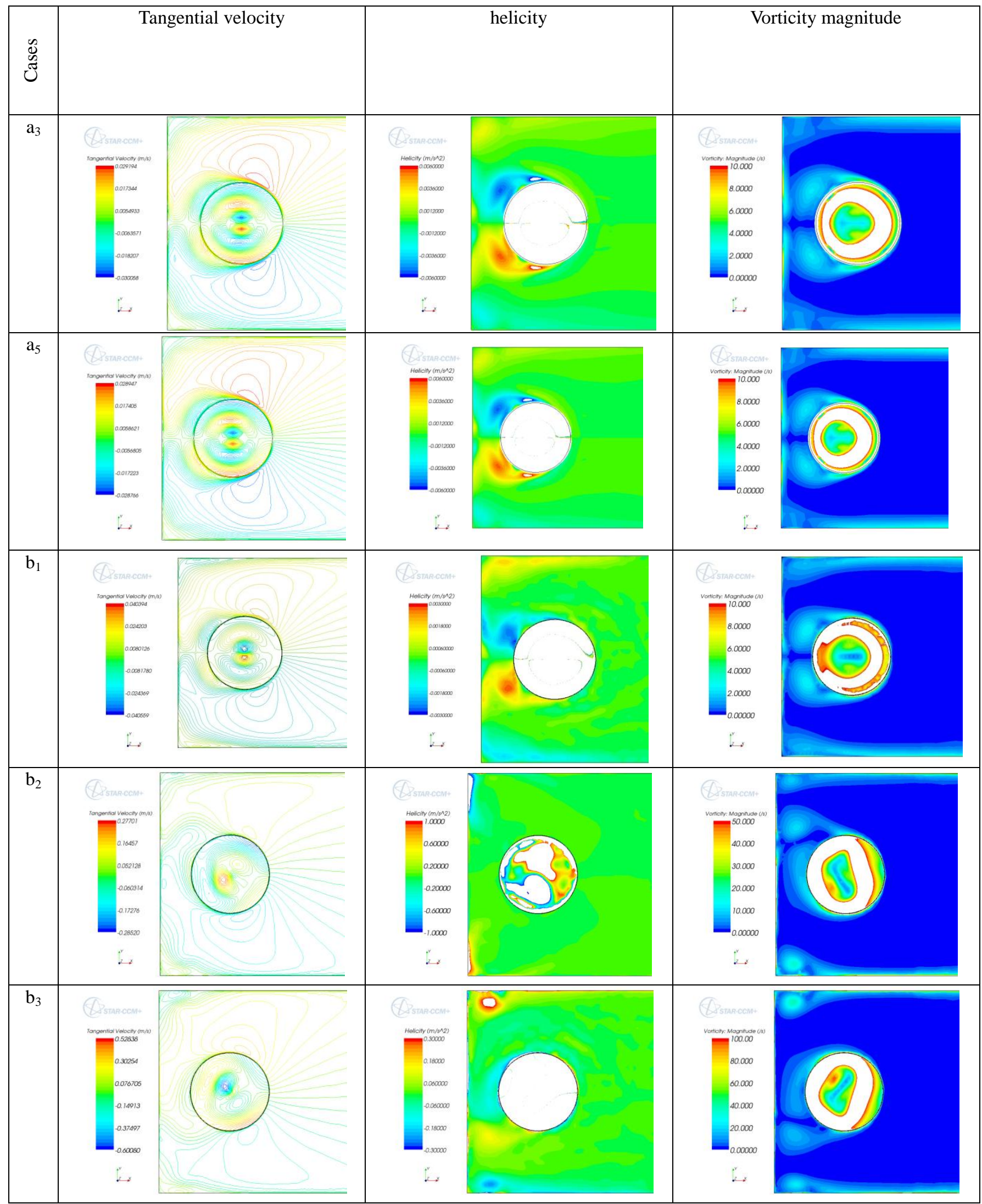

Fig.10 Results: tangential velocity, helicity and vorticity magnitude at free surface without baffle

\subsection{Results including the effect of bellmouth at inlet suction pipe (cases $c_{1}, c_{2}, c_{3}$ and $\left.d\right)$}

The main result concerning the addition of the bellmouth is that symmetry at plane $y=0$ is maintained for higher mass flow rate compared with the previous cases. This is clearly shown on the set of figure 11 where mass flow rate increase with increasing values of cases $c\left(c_{1}\right.$ to $\left.c_{3}\right)$. The critical mass flow rate appears to be at about $\operatorname{Re}=146420 ; \mathrm{Fr}=0,115 ; \mathrm{We}=2978$. 
Another result which can be used to validate part of CFD results concerns the pressure loss coefficient $\xi$, defined as :

$$
\xi=\frac{\left(p_{1}-p_{2}\right)}{\rho \frac{V^{2}}{2}}
$$

Where $\mathrm{p}_{1}$ is the pressure inside sump at free level and $\mathrm{p}_{2}$ is the pressure inside pipe at the same level and $\rho \frac{V^{2}}{2}$ the kinetic energy inside pipe.

Figure 12 summarize the loss coefficient between section 1 and section 2 using all results issued from several cases among those presented in table 1 .

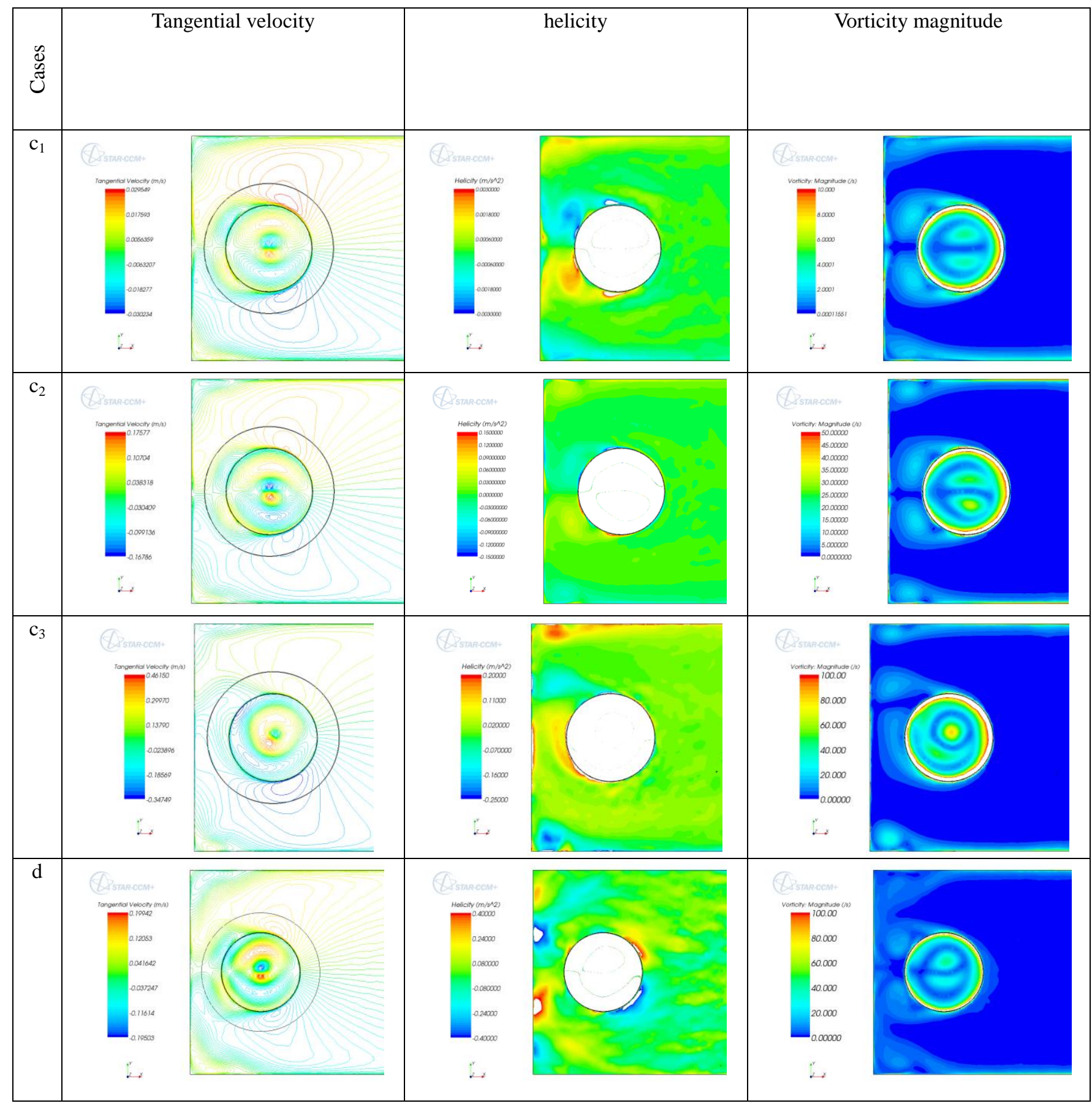

Fig. 11 Results: tangential velocity, helicity and vorticity magnitude at free surface with bellmouth

Case $d$ is a first attempt to calculate two phase flow in such sump configuration. First results are shown Fig. 11, case d. They are to be compared with case $c_{2}$ corresponding to the same mass flow rate $(\mathrm{Re}=146420 ; \mathrm{Fr}=0,115, \mathrm{We}=2978)$. This last case does not show any air entrainment with water probably due to large submergence and high value of water level in the sump. Further 
investigations will be made in order to capture air entrainment in the future. We can see on Figs. 13 and 14 that the convergence history for these cases (case $c_{2}$ and case $d$ ) shows low residuals. Case $d$ is an unsteady calculation with a time step of $0,02 \mathrm{~s}$. This time step is about one percent of the time taken by a wave moving on the free surface from inlet plane to suction inlet pipe.

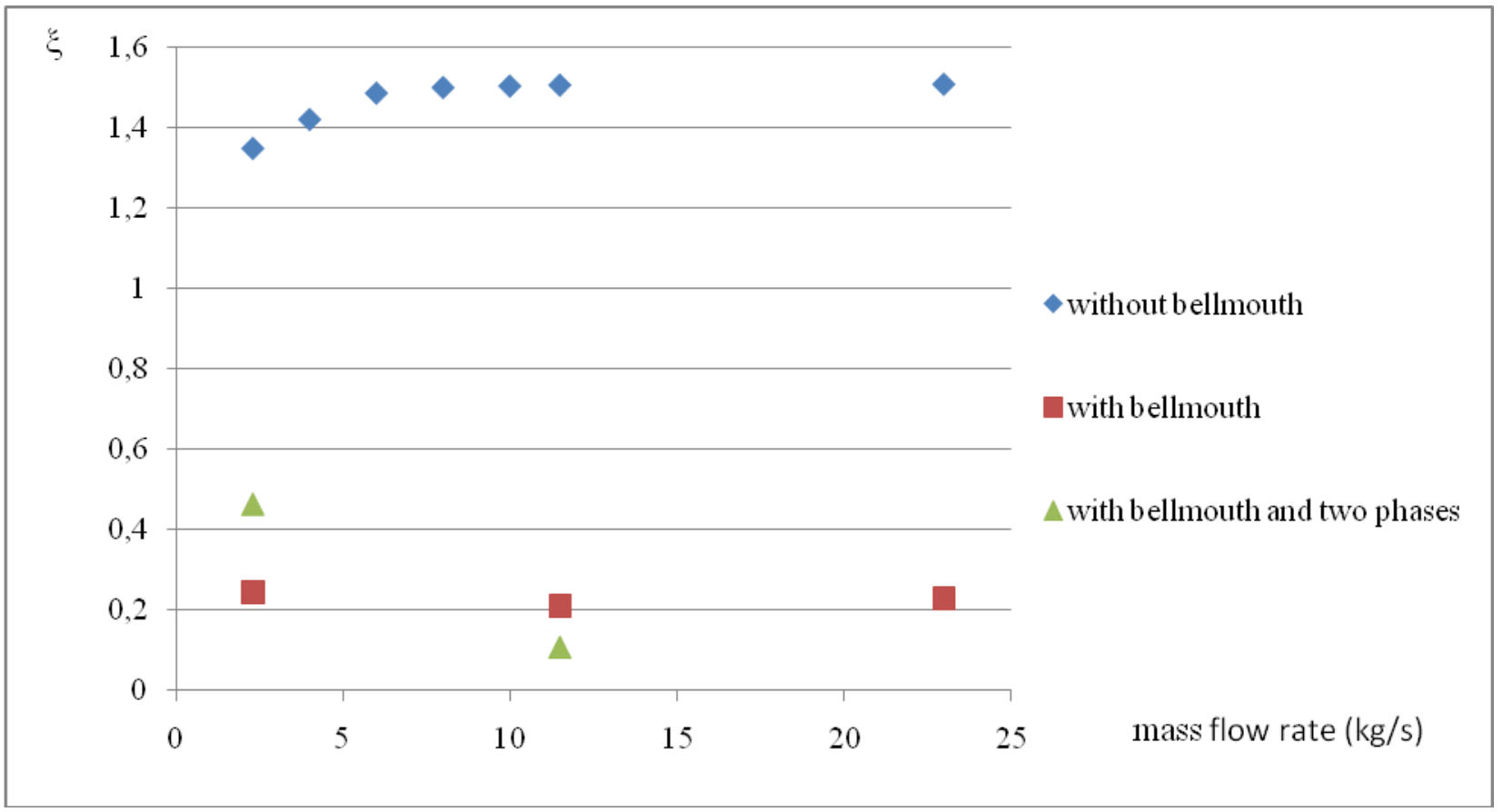

Fig. 12 Pressure loss coefficients between section 1 and section 2

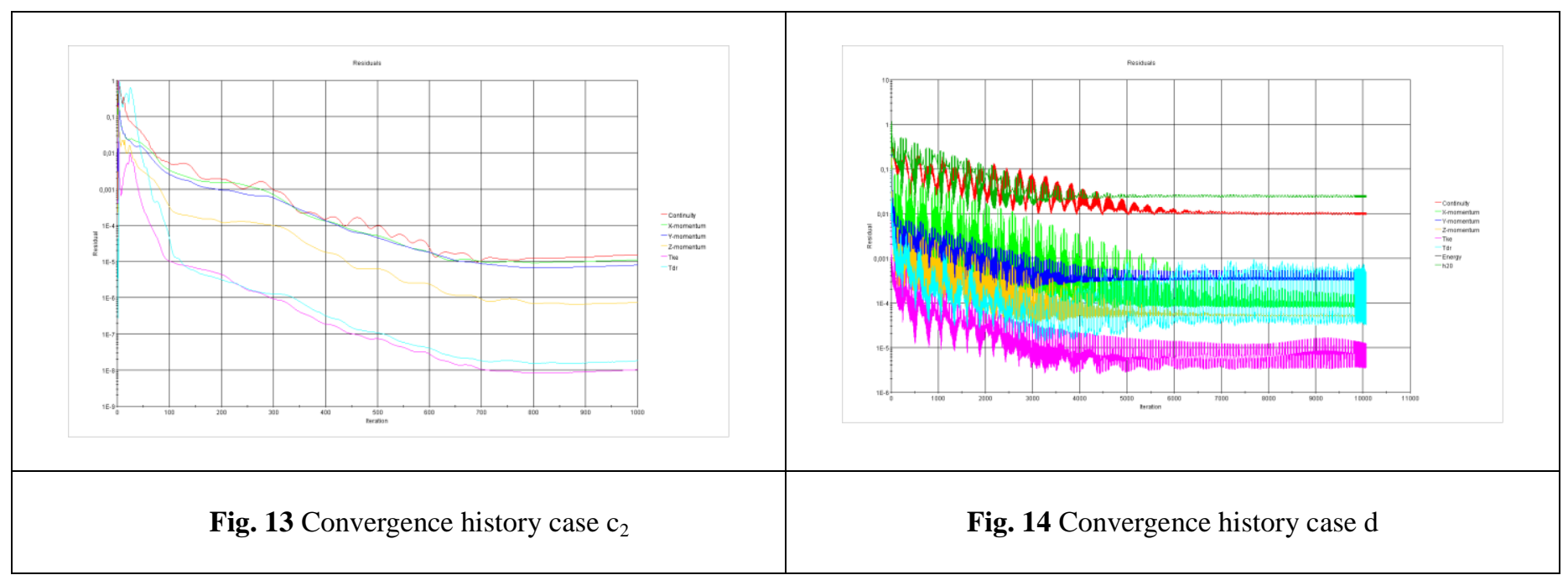

\section{Conclusion}

3D steady flow calculation have been performed on a sump configuration in order to evaluate first the sensivity using two different CFD codes with the same mesh configuration and two different turbulence models.

Results in the sump and in the pipe are comparable with a less extended recirculation zone in the pipe for the STAR CCM+ code compared to FLUENT code.

Using STAR CCM+ with an adapted mesh configuration using hexahedral mesh with prism layer near walls, we can detect a limiting mass flow rate for which flow is not anymore symmetric. The addition of a bellmouth at pipe intake results in an increase of limiting mass flow rate of about three times the initial limiting mass flow rate. These results seem to be quite compatible with general arrangement used in pipe intakes. The calculated loss coefficient between straight inlet pipe and pipe with a bellmouth show significant lower value of losses with $25 \%$ decrease on tangential velocity inside the pipe.

Finally, an attempt has been made to calculate two phase unsteady flow, the results of which are to be studied moreover with stronger mass flow rate and stronger submergence with low water level in order to be able to capture air entrainment. 


\section{Nomenclature}

$\begin{array}{ll}b_{1} & \text { Pipe left wall distance }[\mathrm{m}] \\ b_{2} & \text { Pipe right wall distance }[\mathrm{m}] \\ d & \text { Pipe intake interior diameter }[\mathrm{m}] \\ D & \text { Baffle intake interior diameter }[\mathrm{m}] \\ e & \text { Pipe back wall distance }[\mathrm{m}] \\ F r & \text { Froude number for the pipe submergence } \\ & (=U / \sqrt{g h}) \\ g & \text { Acceleration due to gravity }[\mathrm{m} / \mathrm{s} 2] \\ H & \text { Water level in the sump-pump }[\mathrm{m}] \\ h & \text { Submergence depth for the pipe }[\mathrm{m}] \\ h_{b} & \text { Baffle heigth }[\mathrm{m}] \\ k & \text { kinematic viscosity }[\mathrm{m} 2 / \mathrm{s}] \\ l & \text { Pipe inlet distance }[\mathrm{m}] \\ p & \text { Static pressure }(P a) \\ R e & \text { Reynolds number in the pipe } \\ & \text { (=Vd/v) }\end{array}$

$\begin{array}{ll}U & \text { Mean velocity in the sump }[\mathrm{m}] \\ V & \text { Mean velocity in the intake pipe }[\mathrm{m}] \\ W & \text { Pump-sump width }[\mathrm{m}] \\ \text { We } & \text { Weber number }\left(=V^{2} \rho d / \sigma\right) \\ Z & \text { Clearance distance from floor }[\mathrm{m}] \\ v & \text { kinematic viscosity }\left[\mathrm{m}_{2} / \mathrm{s}\right] \\ \xi & \text { pressure loss coefficient } \\ \rho & \text { Water density. }[\mathrm{kg} / \mathrm{m} 3] \\ \sigma & \text { Coefficient of surface tension }[\mathrm{N} / \mathrm{m}] \\ \omega & \text { Specific dissipation rate }[\mathrm{s}-1]\end{array}$

Subscripts for level free surface inside sump Subscripts for level free surface inside pipe

\section{References}

[1] Anwar, H. O., 1966, "Formation of a Weak Vortex", J. Hydr. Res., 4(1), pp. 1-16.

[2] Anwar, H. O., and Amphlett, M. B., 1980, "Vortices at Vertically in Verted Intake", J. Hydr. Res., 18(2), pp. $123-134$.

[3] Constantinescu, G., and Patel, V. C., 1998, "Numerical Model for Simulation of Pump Intake Flow and Vortices", Jounal of hydraulic Engineering. Div, ASCE, vol 124, pp. 123-134, Iowa Inst of Hydr Res., The Univ of Iowa. Iowa .City, Iowa.

[4] Constantinescu G.S. Patel V.C. ,2000, "Role of Turbulence Model in Prediction of Pump-Bay Vortices", ASCE. Journal of hydraulic Research., Vol.126, No.5,. pp. 123-134.

[5] Daggett, L. L., and Keulegan, G. H., 1972, "Similitude Conditions in Free Surface Vortex Formation”, J. Hydr. Div., ASCE. 100(11), pp. 1565-1580.

[6] Ettema, R., and Nakato, T, 1990, "Hydraulic-Model Study of the Circulation-Water and Essential-Service-Water Pump-Intake structures: Korea Electric Power Corporation Yonggwag Station, Units 3 and 4”, IIHR Limited Distribution Rep. No.339, Iowa Inst.of Hydr. THE Univ of Iowa. Iowa City. Iowa.

[7] Hai-Feng L., Hong-Xum C., Zheng M. YI Z., 2008, "Experimental and Numerical Investigation of Free Surface Vortex.”, Journal of Hydrodynamics., Vol.20, No.4, pp 485- 491.

[8] Abir Issa, Annie-Claude Bayeul-Lainé, Gérard Bois , 2008, "Numerical Simulation of Flow Field Formed in Water PumpSump", 24h Symposium Hydraulic Machinery Systems. Bresil.

[9] Abir Issa, Annie-Claude Bayeul-Lainé, Gérard Bois , 2009, »Numerical study of the influence of geometrical parameters on flow in water sump-pump", $14^{\text {th }}$ International Conference on Fluid Flow Technologies, Budapest, Hungary.

[10] Abir Issa, ,2009, "Etudes hydrauliques de l'influence des géometries des basins sur l'alimentation des pompes”, Ph. D Thesis, Arts et Metiers PARISTECH, Ecole doctorale.

11] Matsui, J., Kamemoto, K., and Okamura. T., 2006," CFD Benchmrak and a Model Experiment on the Flow in Pump Sump". 23th Symposium. Yokohama., 1(10)-(16).

[12] Nakato, T., 1988, "Hydraulic-Labortatory Model Studies of the Circulation-Water Pump-Intake Structure, Florida Power Corporation, Crystal River. Units 4 and 5”, IIHR Rep. No.320, Iowa Inst.of Hydr. The Univ of Iowa. Iowa City.

[13] Nakato, T. 1989, “A Hydraulic-Model Study of the Circulation-Water Pump-Intake Structure”, Laguna Verde Nuclear Power Station, Unit. 1, Comision Federal De Electrcidad. ,IIHR Rep. No.330, Iowa Inst.of Hydr. The Univ of Iowa. Iowa City.

[14] Nakato, T., 1990, "A Hydraulic-Model Study of the Proposed Pump-Intake and Discharge Flume Crystal River CoolingTower Project”, IIHR Rep. No.339, Iowa Inst.of Hydr., the Univ of Iowa. Iowa City.

[15] Nakato, T., 1991, “Improvement of pump-approach flows. A hydraulic model study of Union Electric's Meramec plane circulating-water pump intakes.”, IIHR Rep. No 348, Iowa Inst of Hydro Res. The Univ of Iowa, Iowa City, Iowa.

[16] Tagomori, M, and Gotoch, M., 1989, "Flow patterns and vortices in pump-sumps". Proc, Int Symp on Large Hydr Machinery, China press, Beijing. China, pp. 13-22.

[17] Takata, I, Kawata, Y, Kobayashi, T, and Morinishi, Y., 1992, "Large eddy simulation of unsteady turbulent swirl flow in a pump intake", Proc Inst Computational Fluid Dyn.Elsevier Applied Science, New York, pp. 255-261. 